\title{
Incidence of Active HCV infection amongst Blood Donors of Mardan District, Pakistan
}

\author{
Fawad Karim ${ }^{1}$, Abu Nasar ${ }^{1}$, Ibrar Alam ${ }^{1}$, Iftikhar Alam ${ }^{2}$, Said Hassan ${ }^{3 *}$, Rahmat \\ Gul$^{2}$, Sana Ullah ${ }^{4}$, Muhammad Rizwan ${ }^{3,5}$
}

\begin{abstract}
Hepatitis $\mathrm{C}$ is an ailment of liver caused by hepatitis $\mathrm{C}$ virus (HCV) infection. About $3 \%$ of the world population is infected by this virus. $\mathrm{HCV}$ infection is a leading reason for liver cirrhosis and therefore a major source of hepatocellular carcinoma. The study focused on the incidence of active HCV infection in blood donors of Mardan district of KPK, Pakistan. A total of 5318 blood donors were inspected for the presence of anti-HCV antibodies and HCV-RNA using ICT (immune-chromatographic test), ELISA and RT-PCR at Mardan Medical Complex (MMC), Mardan. Out of these, 157 (2.95\%) were positive by ICT, $60(1.12 \%)$ by ELISA and 56 (1.05\%) for HCV-RNA. The frequency of active HCV infectivity amongst the blood donors from district Mardan, KPK Pakistan was $1.05 \%$. Application of strict measures during blood donor selection and use of proper screening assays such as ELISA in place of ICT devices can give a more accurate picture so that the incidence of this viral infection in HCV negative blood recipients can be reduced.
\end{abstract}

Keywords: HCV - ELISA - RT-PCR - viral infection rates

Asian Pac J Cancer Prev, 17 (1), 235-238

\section{Introduction}

The main reason of hepatitis $\mathrm{C}$ is hepatitis $\mathrm{C}$ virus (HCV) which was first acknowledged in 1989 (Alam et al., 2013). The infection by hepatitis $C$ virus is the main cause of prolonged hepatitis leading to cirrhosis of liver followed by carcinoma of hepatic cells. HCV contributes to about $27 \%$ of cirrhosis and $25 \%$ hepatocellular carcinoma (HCC) (Alter et al., 2007). It is an enclosed virus and is a species of family Flaviviridae. The genetic analysis of $\mathrm{HCV}$ virus revealed that it is a virus enclosing positive sense single stranded RNA genome. The RNA molecule is 9600 nucleotide bases long.

HCV has a remarkable diversity in its genome. Until now about 30 genotypes of HCV have been reported worldwide (Kato et al., 2000). The incubation period of $\mathrm{HCV}$ virus for creating an acute hepatitis $\mathrm{C}$ infection in a host ranges from 2-12 weeks. Symptoms are informed in only $10-15 \%$ patients (Ozaras et al., 2009). Among the infected people, about $70 \%$ patients fail to remove the virus during acute stage which leads to chronic hepatitis. Maximum people who have acute hepatitis $\mathrm{C}$ presented no symptoms for it and do not know if they are infected. HCV can lead to chronic liver disease which is contributing to 8000-10000 deaths per year (Moyer et al., 1999). Among the total world population, about $3 \%$ is tagged HCV infected by World Health Organization (WHO) (WHO:
Diseases; Hepatitis C). HCV diagnosis generally depends on the recognition of anti-HCV antibody in blood by an Enzyme Immuno Essay (EIA). During initial symptoms of disease the antibodies are not well generated in about $30 \%$ of patients, so the sighting of $\mathrm{HCV}$ depend on detection of HCV RNA which can be spotted within 7-14 days after infection with subsequent high eminent alanine aminotransferase values (Ozaras et al., 2009).

According to most of studies the viral load and the genotype of virus have no effect on the severity of disease and its progression it also does not predict the natural history. During infection by $\mathrm{HCV}$, the infected individual's immune system develop antibodies against core $(\mathrm{C})$ protein and several non-structure proteins of the virus. CD8+ cytotoxic T-cells are developed in the liver and CD4+ helper T-cells are found in the outlying blood of chronically infected individuals (WHO: Diseases; Hepatitis C). Prevalence of $\mathrm{HCV}$ in different countries ranges from $0.3 \%$ in Australia, $8.5 \%$ in England and Germany, Egypt has highest prevalence having more than 6 million positive people and Brazil having about 2 million seropositive subjects (Bruggmann et al., 2014). In Pakistan the prevalence of $\mathrm{HCV}$ is $4.7 \%$ with genotype $3 \mathrm{a}$ being dominant (Afridi et al., 2015). In KPK province of Pakistan the incidence rates of $\mathrm{HCV}$ in diverse groups of people ranges from $3.59 \%$ in thalassemia patients, $4.19 \%$ in dialysis patients, $1.19 \%$ in major surgery patients,

${ }^{1}$ Department of Biotechnology, ${ }^{2}$ Department of Human Nutrition and Dietetics (HND), Bacha Khan University Charsadda, ${ }^{3}$ Center of Biotechnology and Microbiology, University of Peshawar, KP, ${ }^{4}$ Department of Animal Science Quaid-i-Azam University Islamabad, ${ }^{5}$ Department of Microbiology, Abasyn University Peshawar, KPK-Pakistan *For correspondence: saidhassan15@yahoo.com 
Fawad Karim et al

$2.99 \%$ in patients having dental procedures and $3.59 \%$ in injecting drug users (IDU) (Ali et al., 2011). Alcohol intake, presence of $\mathrm{HBV}$ already $\mathrm{HBV} / \mathrm{HCV}$ co-infection are the factors which promote disease progression. The spread of HCV mainly happens by contact to the contaminated blood as well as plasma products. The transmission is less reported by household and sexual activities (WHO: Diseases; Hepatitis C). Further threat elements for anti HCV positive test include transfusion of blood from infected person, illegal injection drug use intravenously, parenteral exposure such as tattooing and acupuncture, non-sterile and non-disposable equipment in dental procedure, occupational exposure to $\mathrm{HCV}$, sexual intercourse with an injecting drug user or HCV positive individual (high risk sexual behavior) (Ajaccio et al., 2002). In developing countries like Pakistan, HCV is mainly transmitted through blood transfusion the reason could be the lack of resources, un-well trained staff, feeble infrastructure and ineffectual screening of blood donors for HCV infection (Akhtar et al., 2004). During this study our efforts were to unveil the prevalence of $\mathrm{HCV}$ by investigating antibodies against HCV and HCV-RNA in healthy blood donors. The purpose of our study was finding out the occurrence of $\mathrm{HCV}$ antibodies in the blood and to find out the incidence of actual HCV infection in the blood donors, resident in Mardan, KPK, Pakistan and also to compare the performance of screening technique for finding $\mathrm{HCV}$ antibodies.

\section{Materials and Methods}

\section{Site of study and collection of samples}

Blood samples were collected from District Head Quarters hospital and Mardan Medical Complex Mardan, KPK Pakistan. The serological tests were performed at screening lab and PCR lab of Mardan Medical Complex Mardan. All the blood donors were resident of Mardan. Those blood donors were studied who came for blood donation during the period of March 2015 to July 2015. These blood donors were declared fit for donation by the medical staff of the blood bank. 5 milliliters of blood were taken from the blood donor with sterile syringe. Syringe was emptied in an EDTA specimen tube and centrifuged for 5 minutes at 2500 revolution per minute (rpm). Plasma was separated from the tube and was ready for further analysis. These samples were then checked by three types of screening techniques in order to find out HCV antibodies and HCV RNA, moreover to evaluate the efficacy of the screening technique such as ICT and ELISA for screening of HCV in patient.

\section{Immuno-chromatographic test ICT}

Serum or plasma collected was checked for the occurrence of anti-HCV antibodies using ICT applying manufacturer`s protocol. Immune-chromatographic strips used in this purpose were supplied from two makers first was Accurate and second Acon (Acon, USA).

Enzyme-linked immunosorbant assay (ELISA)

Samples confirmed positive by ICT were further analyzed by another assay named ELISA to generate more accurate result. The ICT positive sera were checked using ELISA (S.A, Barcelona Spain) followed the protocol provided by the manufacturer as followed by (Akhtar et al. 2015). Those samples which were confirmed positive by ELISA were then treated for extraction of RNA.

Nucleic acid isolation and polymerase chain reaction

Positive ELISA samples were sent to PCR laboratory where RNA was extracted from them using the RNA extraction kit made by Sacace (Sacace, Italy) followed by RT-PCR. The kit used for RT- PCR was manufactured by Sacace biotechnologies (Sacace, Italy) Cepheid smart cycler was used for the Real-Time PCR following the guidelines given with the Cepheid smart cycler (Cepheid, California, U.S).

\section{Results}

HCV incidence amongst young blood donor of district Mardan $K P K$

Total 5318 voluntary blood donors were tested. ICT

Table 1. Enzyme Immuno Essays, RT-PCR Result and their Percentage

\begin{tabular}{lcccc}
\hline MONTHs & $\begin{array}{c}\text { No. of } \\
\text { donors }\end{array}$ & $\begin{array}{c}\text { ICT } \\
(+ \text { ive })\end{array}$ & $\begin{array}{c}\text { ELISA } \\
\text { (+ive) }\end{array}$ & $\begin{array}{c}\text { RT-PCR } \\
(+ \text { ive })\end{array}$ \\
\hline March & 1390 & 48 & 17 & 16 \\
April & 1170 & 45 & 13 & 12 \\
May & 1134 & 26 & 10 & 10 \\
June & 792 & 18 & 9 & 8 \\
July & 832 & 20 & 11 & 10 \\
5 & 5318 & $157(2.95 \%)$ & $60(1.12 \%)$ & $56(1.05 \%)$ \\
\hline
\end{tabular}

Table 2. Laboratory Parameters of ELISA Positive Patients

\begin{tabular}{cccc}
\hline Serial no. & Laboratory tests & Mean value & Normal range \\
\hline 1 & SGPT (ALT) & 85.28 & Upto 40u/l \\
2 & T.Billirubine & 0.76 & Upto $1.0 \mathrm{mg} / \mathrm{dl}$ \\
3 & Alkaline Phosphatase & 80.93 & $120250 \mathrm{u} / 1$ \\
\hline
\end{tabular}

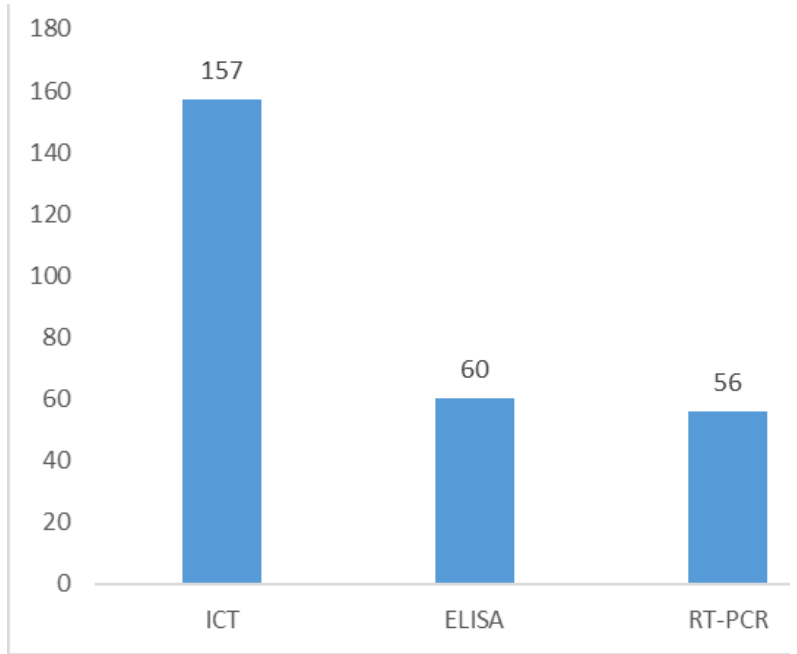

Figure 1. No of Positive Subjects Screened Through ICT, ELISA and PCR 
was used for finding HCV antibodies. Among 5318 volunteers only $157(2.95 \%)$ were ICT positive shown in Table: 1.

The serum samples which were confirmed affirmative using ICT were furthermore analyzed with the use of ELISA in which we gain $60(1.12 \%)$ positive results (Table: 1$)$. The liver function test values of ELISA positive patients are given in table: 2. ELISA positive samples were further more processed for RT-PCR. 56 (1.05\%) samples were confirmed to be actively infected with $\mathrm{HCV}$ and harbor HCV-RNA. Table: 1, which shows prevalence of anti-HCV antibodies tested by ICT and ELISA also HCVRNA among blood donors of Mardan, KPK Pakistan. 157 patients were positive by ICT, 60 patients were Elisa positive and 56 patients were RT-PCR positive. Table: 2 shows the levels of different liver enzymes of ELISA positive patients before starting therapy. Mean values and their normal ranges are given in the table. Figure: 1 shows the number of positive patients, who are screened through various techniques and shows their comparison with each other.

\section{Discussion}

The viral hepatitis seems to be widespread in general population of Pakistan and also in most parts of the world which is contributing to chronic liver disease. A partially contributing factor to the spread of HCV seems to be the absence of proper screening technique in screening blood for probable $\mathrm{HCV}$ infection at hospitals and others health centers because through unscreened blood, the blood recipients can receive a probable $\mathrm{HCV}$ infection. Also it is very hard to avoid spread of infectious diseases during blood transfusions due to limited resources. Strict measures during donor's selection and use of sensitive screening tests can aid in the prevention of these diseases. Earlier studies done on HCV prevalence which included blood donors or general population from KPK province was grounded on finding anti-HCV antibodies (Khan et al., 2004; Ahmad A et al., 2006; Ahmad et al., 2009). These studies done in KPK province including Mardan (Khan et al., 2004), district Swat (Ahmad et al., 2006), NWFP (KPK) (Ahmad et al., 2004) and North West Pakistan (Khattak et al., 2008) has publicized the prevalence rates of $\mathrm{HCV}$ in blood donors to be $9 \%, 2.23 \%, 2.2 \%$, and $4.1 \%$ respectively. Studies conducted in other parts of the country including Hyderabad (Tunio et al., 2013), Interior Sindh (Mujeeb et al., 2008) and Kurram Agency (Bangash et al., 2009; Munaf et al., 2014) has shown prevalence rates of $3.45 \%, 5.7 \%$, and $1.1 \%$ respectively.

Whilst the bulk of these studies carried out was dependent on discovery of antibodies generated counter to $\mathrm{HCV}$ and active $\mathrm{HCV}$ infection remained in doubt. In our study we tried to find prevalence of active $\mathrm{HCV}$ infection by conducting antibodies test as well as RT-PCR based HCV RNA detection. This can accurately find out HCV infection in the blood donors belonging to Mardan region.

In this study the blood screened with ICT devices shown that $2.95 \%$ of the blood donors were anti-HCV antibodies positive, this rate of prevalence comes in the range of the studies mentioned above. With the aim to enhance the results of our screening process, the positive ICT sera were examined using third generation of ELISA because a common problem called false positivity is linked with ICT devices (Grobusch et al., 1999; Rahman et al., 2008; Srivastava et al., 2009). ELISA tests specified that $1.12 \%$ of the blood donors were anti-HCV positive. This result shows that the ICT devices are not enough good to represent the exact prevalence of $\mathrm{HCV}$ infection. In most health centers ICT devices are used to check HCV infection. It is suggested that ELISA should be given more preference over the ICT devices in those departments where immigration of employees is associated. Nowadays many manufacturers are trying their best to produce ELISA which can figure out $\mathrm{HCV}$ core antigen in the blood. Developing countries like Pakistan which cannot afford Nucleic acid Amplification Test (NAT) for screening blood can take great advantage from these essays in addition to ICT devices. For the verification that whether active infection is present or not, we checked the samples positive from ELISA by using real-time PCR assay which specified with its results that that $1.05 \%$ blood donors are actively infected and harbors HCV-RNA. The probable explanation for this decrease can be the presence of antibodies in patients who are treated completely or the nature of the disease. The frequency of active infection of HCV amongst the blood donors from Mardan region of KPK, Pakistan is $1.05 \%$. This is considerably low percentage while keeping in view the previous publicized rates. Application of strict measures during blood donor selection and use of proper screening essay such as ELISA in place of ICT device can decrease the incidence of this viral infection in $\mathrm{HCV}$ negative blood recipients.

In conclusion, the frequency of active infection of $\mathrm{HCV}$ amongst the blood donors from Mardan region of KPK, Pakistan is $1.05 \%$. This is considerably low percentage while keeping in view the previous publicized rates. Application of strict measures during blood donor selection and use of proper screening essay such as ELISA in place of ICT device can decrease the incidence of this viral infection in $\mathrm{HCV}$ negative blood recipients.

\section{References}

Afridi SQ, Ali MM, Awan F (2015). Molecular epidemiology and viral load of HCV in different regions of Punjab, Pakistan. $J$ Hepatol, 62, 1256-64.

Ahmed A, (2006). Anti-HCV in healthy voluntary blood donors in district Swat. J Postgrad Med Inst, 20, 187-90.

Ahmad J, Taj AS, Rahim A, et al (2004). Frequency of Hepatitis $\mathrm{B}$ and Hepatitis $\mathrm{C}$ in healthy blood donors of NWFP a single center experience. J Postgrad Med Inst, 18, 343-52.

Akhtar S, Moatter T, (2004). Hepatitis C virus infection in polytransfused thalassemic children in Pakistan. Indian Pediatrics, 41, 1072-3.

Ahmad A, Ahmad B, Ali A, et al (2009). Seroprevalence of HBsAg and anti HCV in general healthy population of Swat district with frequency of different HCV Genotypes. Pakistan J Med Sci, 25, 744-748.

Ahmad B, Ali S, Ali I, Azam S, Bashir S (2012). Response rates of standard interferon therapy in chronic $\mathrm{HCV}$ patients of Khyber Pakhtunkhwa (KPK). Virol J, 9, 18.

Akhtar N, Bilal M, Rizwan M, et al (2015). Genotypes of Hepatitis C Virus in relapsed and non-respondent patients 
and their response to anti-viral therapy in district Mardan, Khyber Pakhtunkhawa, Pakistan. Asian Pac J Cancer Prev, 16, $1037-40$.

Ajaccio BM, Sandra CF, (2002). Risk factors for hepatitis C virus infection among blood donors in southern Brazil: a case-control study. BMC Gastroenterol, 2, 18.

Alam I, Alam I, Ali I, et al (2014). Weight loss in HCV patients can be used as a surrogate marker for evaluation of interferon $($ IFN- $\alpha$ ) treatment efficacy - A prospective pilot study. Pak $J$ Pharm Sci, 27, 571-6.

Alter MJ (2007). Epidemiology of hepatitis C virus infection. World J Gastroenterol, 13, 2436-41.

Bangash MH, (2009). Prevalence of hepatitis B and hepatitis C among healthy blood donors at Kurram agency. $J$ Postgraduate Med Inst, 23, 140-5.

Bruggmann P (2014). Historical epidemiology of hepatitis C virus (HCV) in selected countries. J Viral Hepatitis, 21, 5-33.

Grobusch MP, Alpermann U, Schwenke S, et al (1999). False positive rapid tests for malaria in patients with rheumatoid factor. Lancet, 3, 353-297.

Ijaz Ali, Lubna Siddique, et al (2011). Prevalence of HCV among the high risk groups in Khyber Pakhtunkhwa .Virol J, 8, 296.

Kato N (2000). Genome of human hepatitis C virus (HCV), gene organization, sequence diversity, and variation. Microbial and Comparative Genomics, 5, 129-51.

Khan MSA, Khalid M, Ayub N, et al (2004). Seroprevalence and risk factors of Hepatitis $\mathrm{C}$ virus (HCV) in Mardan, NWFP. Rawal Med J, 29, 57-60.

Khattak MN, Akhtar S, Mahmud S, (2008). Factors influencing hepatitis $\mathrm{C}$ virus sero-prevalence among blood donors in north west pakistan. J Public Health Policy, 29, 207-25.

Moyer LA, Mast EE, Alter MJ, et al (1999). Hepatitis C, routine serologic testing and diagnosis. Am Fam Physician, 59, 79-88.

Mujeeb SA, Pearce MS, (2008). Temporal trends in hepatitis B and $\mathrm{C}$ infection in family blood donors from interior Sindh, Pakistan. Biomed Central Infectious Diseases, 8, 43.

Munaf A, Memon MS, Kumar P, Ahmed S, Kumar MB (2014). Comparison of viral hepatitis-associated hepatocellular carcinoma due to $\mathrm{HBV}$ and $\mathrm{HCV}$ - cohort from liver clinics in Pakistan. Asian Pac J Cancer Prev, 15, 7563-7.

Ozaras R, Tahan V (2009). Acute hepatitis C prevention and treatment. Expert Review Anti-Infective Therapy, 7, 351-61.

Srivastava AV, Czerska B, Williams C, et al (2009). High rates of false-positive hepatitis $\mathrm{C}$ antibody tests can occur after left ventricular assist device implantation. J Heart Lung Transplant, 28, 159-60.

Tunio SA. 2013. Seroprevalence of Hepatitis B and Hepatitis $\mathrm{C}$ among blood donors in Hyderabad, Pakistan. Gomal $J$ Med Sci, 1, 2.

WHO:Diseases; HepatitisC. (http://www.who.int/csr/disease/ hepatitis/whocdscsrlyo2003/en/index3.html), (Accessed in 2015). 